\title{
A NIGHT-LIGHTING TECHNIQUE FOR CAPTURING PERUVIAN THICK-KNEES (BURHINUS SUPERCILIARIS) AND FIRST DATA ON MOLT SEQUENCE AND BIOMETRICS
}

\author{
Carlos CAMACHO ${ }^{1 *}$, SANTIAgo TORRES ${ }^{1}$
}

\begin{abstract}
${ }^{1}$ Aves \& Conservación (BirdLife en Ecuador). Joaquín Tinajero E3-E5 y Jorge Drom, Quito, Ecuador *Current address: Department of Evolutionary Ecology, Estación Biológica de Doñana (EBD-CSIC), Américo Vespucio 41092, Seville, Spain. <ccamacho@ebd.csic.es>
\end{abstract}

Recibido: 16/10/2013; aceptado: 30/07/2014

Camacho, C. \& Torres, S. 2015. A night-lighting technique for capturing Peruvian thick-knees (Burhinus superciliaris) and first data on molt sequence and biometrics. Acta Zoológica Mexicana (n. s.), 31(1): 36-40.

ABSTRACT. The Peruvian thick-knee Burhinus superciliaris (Tschudi, 1843) is an uncommon species with highly cryptic behavior, and is thus difficult to capture and monitor. As a result, many questions remain about their basic life-history strategies and conservation status. During January and February 2009, a night-lighting technique was developed for the selective capture of Peruvian Thick-knees in southwestern Ecuador, and the molt sequence and biometrics of freeranging individuals were documented for the first time. Birds were located (24 sightings) and captured (four individuals) along $48 \mathrm{~km}$ of unpaved roads using a lightweight LED flashlight and a 80-cm diameter hand-held net. On average, capture success was 0.29 birds captured/session (range, $0-2$ ) out of 0.64 attempts per session (range, $0-4$ ) and a capture rate of 0.44 birds/attempt ( $n=9$ attempts). The molt progress was sequential and highly symmetrical and no simultaneous growing of feathers from the same feather tract was observed, except in secondaries. In contrast to the rectrices, primary feathers were shed from the innermost to the outermost, whereas birds seemed to have two molting centers for secondaries. The high recapture opportunities of this method allows monitoring the molt sequence, weight gain, spatial use and other life-history parameters of the Peruvian Thick-knee and possibly other small and medium-sized birds.

Key words: Burhinidae, selective capture, life history, population monitoring, Ecuador.

\section{INTRODUCTION}

The Peruvian Thick-knee Burhinus superciliaris is an uncommon species that inhabits dry agricultural areas and semi-arid scrublands near the coasts of southern Ecuador, Peru and northern Chile (Hume 1996, Canevari et al. 2001). In recent decades, the number of records of Peruvian Thick-knees has increased significantly in the north of Chile (Miranda et al. 2001), so this area seems to be a fairly recent range extension towards the south (Aguirre et al. 2006). In contrast, the species shows a restricted distribution at the northern edge of its world range (i.e. Ecuador), where Thick-knee populations continue to decline due to the growth of coastal settlements (Santander et al. 2006, Camacho 2010). Reliable estimation of life-history
Camacho, C. \& Torres, S. 2015. Técnica de deslumbramiento nocturno para la captura de alcaravanes peruanos (Burhinus superciliaris) y primeros datos sobre secuencia de muda y biometría. Acta Zoológica Mexicana (n. s.), 31(1): 36-40.

RESUMEN. El alcaraván peruano Burhinus superciliaris (Tschudi, 1843) es una especie rara con un comportamiento muy críptico, lo que dificulta su captura y monitoreo. Como resultado, aún desconocemos numerosos aspectos de su biología y estado de conservación. En enero y febrero de 2009, se desarrolló una técnica de deslumbramiento noc-turno para la captura selectiva de Alcaravanes Peruanos en el suroeste de Ecuador, y se documentaron por primera vez los patrones de muda y la biometría de individuos en libertad. Las aves se localizaron (24 observaciones) y capturaron (cuatro individuos) a lo largo de $48 \mathrm{~km}$ de carreteras no asfaltadas utilizando un linterna ligera LED y una red de mano de $80 \mathrm{~cm}$ de diámetro. En promedio, el éxito de captura fue de 0.29 aves capturadas/sesión (rango, 0-2), a razón de 0.64 intentos por sesión (rango, 0-4) y una tasa de captura de 0.44 aves/intento ( $n=9$ intentos). El proceso de muda fue secuencial, muy simétrico y no se observó crecimiento simultáneo de plumas del mismo grupo salvo en las secundarias. Las primarias, al contrario que las rectrices, se reemplazaron desde el interior hacia el exterior, mientras que las aves parecían mostrar dos centros de muda para las secundarias. Las elevadas oportunidades de recaptura de este método permiten monitorear la secuencia de muda, ganancia de peso, uso del espacio y otros aspectos de la biología del Alcaraván peruano y, posiblemente, de otras aves de tamaño pequeño y mediano.

Palabras clave: Burhinidae, captura selectiva, historia de vida, moni-toreo de poblaciones, Ecuador.

parameters is crucial to assess and ensure the viability of animal populations (Lindström 1999), but costly studies involving the capture and recapture of marked individuals are usually required. The difficulty of detection of Peruvian Thick-knees due to their highly cryptic habits and color patterns, combined with the lack of capturing methods that have proved successful, represent serious barriers to obtain accurate estimates of abundance to evaluate their current conservation status.

Limited trapping techniques applied to genus Burhinus exist in the literature (e.g. Andrews 1997, MorenoOpo 2003). Methods used to capture birds are mostly dependent on the characteristics and behavior of the target species and the capture period (Bub 1991). However, the 
capture of birds can be time-demanding when individuals are difficult to find due to low density or cryptic plumage (Benítez-López et al. 2011). Peruvian Thick-knees are scarce throughout much of its world range (Camacho 2012) and remain relatively inactive during daylight hours (Iannacone et al. 2012). Nevertheless, roosting flocks split up to forage at dusk and birds concentrate on nearby roads, thus providing researchers with increased capture opportunities during the night (Camacho 2012). The night-lighting technique has been widely used to capture a variety of nocturnal and diurnal bird species during the night (e.g. Jackson 1984, King et al. 1994). Briefly, the night-lighting technique consists in using a powerful light to locate and dazzle birds to approach and catch them with a hand-held net (Benítez-López et al. 2011). This capturing method has proved highly successful for numerous avian orders, after attending to improvements for particular groups (e.g. waterfowl, Cummings \& Hewitt 1964, Drewien et al. 1967, Bishop \& Barrat 1969; grassland birds, Ward et al. 1989) or target species (e.g. nightjars, Jackson 1984; cormorants, King et al. 1994; woodcocks, Duriez et al. 2005: grouse, Benítez-López et al. 2011) and it is thus expected to make finding Thickknees easier and allow targeting particular individuals.

Molt descriptions in shorebirds are currently available for many species (e.g. Holmgren \& Hedenstrom 1995, Serra 2001, Summers et al. 2004), but those of Burhinidae remains limited (Giunchi et al. 2008). Particularly in the Peruvian Thick-knee, most basic questions about its life history remain unknown (e.g. morphometrics, molt), except for some recent works on its social and individual behavior (Camacho 2012, Iannacone et al. 2012). A discrete population of Peruvian Thick-knees still survives in Santa Elena (Ridgely \& Greenfield 2001), where occasional sightings have taken place (Camacho 2010). In this paper, we describe how the night-lighting technique can be used to selectively capture flight-capable Peruvian Thick-knees during their peak activity period. This paper also provides the first data from free-ranging Peruvian Thick-knees on biometrics and molt sequence.

\section{MATERIALS AND METHODS}

Fieldwork was conducted in January and February 2009 (14 nights) in the Peninsula of Santa Elena (Ecuador; $2^{\circ}$ $12^{\prime} \mathrm{S}, 80^{\circ} 59^{\prime} \mathrm{W}$ ). The study plot consisted of a $48-\mathrm{km}$ road circuit (14 transects) crossing interspersed remnants of tropical dry forest (Fig. 1B; see Camacho 2010 for a detailed description of the study area). Capture sessions were undertaken every $3-4$ days on lightly $(<30 \%)$ clouded nights with no precipitation and low $(<10 \mathrm{~km} / \mathrm{h})$ wind velocity. Driving a vehicle between 20:00 h and 1:00 h
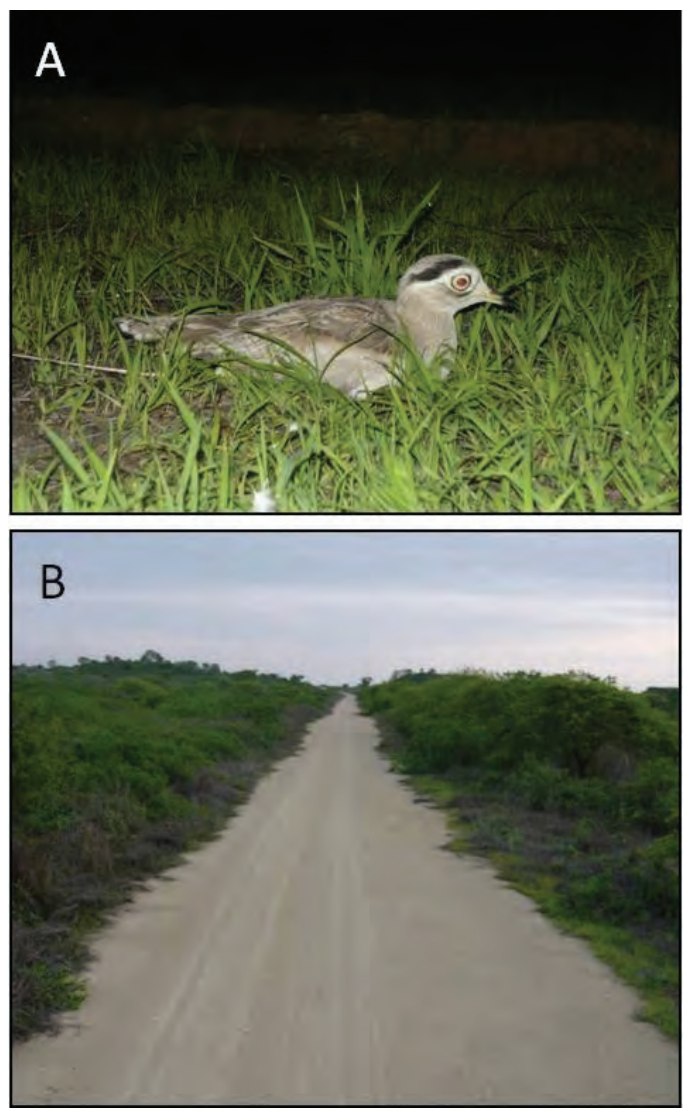

Figure 1. A. Peruvian thick-knee prior to release.

B. Road stretch in which Peruvian thick-knees were located in darkness and trapped by using the night-lighting technique.

at a constant speed of $30 \mathrm{~km} / \mathrm{h}$, we located the birds in darkness using the car lights. Although the eyes poorly reflected the spotlight, Peruvian Thick-knees were easily recognizable from a distance of $100-200 \mathrm{~m}$ due to their large size ( $\sim 0 \mathrm{~cm}$ height and $450 \mathrm{~g}$ of body mass). The catching equipment consisted of a dark-colored hand-held net ( $80 \mathrm{~cm}$ diameter, $20-\mathrm{mm}$ mesh) fitted to a $30-\mathrm{cm}$ plastic pole and a lightweight flashlight with six LED lamps that had been previously modified to get relatively a narrow light beam (1-2 m radius) and thus avoid lighting ourselves. Once a target individual was located, we continued moving forward slowly until placing the car about 15 meters away from the bird. Then, one observer (CC) got out of the car stealthily and immediately dazzled the bird with the flashlight at the same time another observer (ST) turned off the car lights. We kept the engine on to cam-ouflage the footsteps while approaching the bird, walk-ing barefoot or using quilted soles. The bird was finally trapped $1-0.5 \mathrm{~m}$ from the observer using the hand-held net. All the birds were marked with colored leg bands to allow individual recognition.

We recorded the capture effort (h/night) and quantified the trapping chance (birds encountered per hour and $\mathrm{km}$ ). 
To assess the efficiency of the method, we recorded (1) the capture success (number of birds captured/session), (2) the number of attempts/session and (3) the capture rate (number of birds captured/attempt) considering that an attempt was performed when an observer managed to approach an individual.

Biometrics and molt sequence. No information on the molt patterns or biometrics of free ranging Peruvian Thick-knees exists in the literature. Therefore, after trapping the birds, we collected field data to help fulfilling these important gaps in the life history of the species. All individuals were measured for wing chord and tail length to the nearest $\pm 0.5 \mathrm{~mm}$ following the method of Svensson (1996). We also measured tarsus (tarso-metetarsal bone) length, culmen (up to the point the bill joins the skull) and central toe length (measured on the upper side from the base of the claw to the joint between the toe and the tarsus) to the nearest $0.1 \mathrm{~mm}$ using a digital caliper. Birds were weighed with a 500 -g spring balance to the nearest $0.1 \mathrm{~g}$. The molt sequence was assessed following the method of Ginn \& Melville (1983) by scoring each feather according to its state of growth $(0=$ old feather; 1 = old feather missing or new feather in pin; 2 = new feather just emerging from sheath up to one-third grown; 3 = new feather between one and two-thirds grown; 4 = two-thirds to fully grown, but waxy sheath still at its base; 5 = new feather fully-grown). The 10 innermost primaries (PP), numbered from innermost to outermost, and the 12 outermost secondaries (SS), numbered from outermost to innermost, were considered in both wings. Tail feathers (RR) were also evaluated.

\section{RESULTS}

During the course of transect counts, we encountered 24 Peruvian thick-knees (of which 30\% were already banded) and captured four flight-capable individuals. No groups were detected during night, but $50 \%$ of the birds ( $n=19$ sighting episodes) were linked to another individual. Monitoring of two focal individuals during four 0.5 h-sessions showed that they spent most of the nighttime hours foraging together within a radius of $250 \mathrm{~m}$ around the same road stretch.

Mean capture effort was $1.1 \mathrm{~h} /$ night (range, 0.3-2.4) and varied daily between one and nine transects, covering a mean of $3.1 \mathrm{~km}$ a day (range, 0.5-9.2). On average, the trapping chance per capture session was 1.52 birds/h (range, $0-4$ ) and $0.55 \mathrm{birds} / \mathrm{km}$ (range, 0-3.89). The mean capture success was 0.29 birds captured/session (range, $0-2$ ) out of 0.64 attempts per session (range, $0-4)$ and a capture rate of 0.44 birds captured/attempt ( $n=9$ attempts). During the capture, as the observer ap- proached the bird, it often escaped running, covering short distances that varied from one to $10 \mathrm{~m}$. While escaping, the birds usually uttered a series of high-pitched vocalizations and set the eyes on the light source, walking laterally. This could be repeated up to 3-4 times, until covering $\leq 600 \mathrm{~m}$. After $2-5$ attempts, the bird usually escaped by flying away, which always meant the end of the attempt. Flight initiation distance, the distance at which the bird flees from an approaching observer, varied from 10 to $20 \mathrm{~m}$ and the bird often landed $100-200 \mathrm{~m}$ farther. When the capture was successful, thick-knees tended to lie still against the ground when the hand net fell over them, an important factor maintaining the integrity of the bird. Birds were always apparently calm when captured and flew upon release (Fig. 1A). No individual died or get injured when captured or handled.

Biometrics and molt sequence. Body measurements obtained were the following (mean $\pm \mathrm{SD}$ ): wing chord: $232.13 \mathrm{~mm} \pm 2.39$; tail length: $122.75 \mathrm{~mm} \pm 5.38$; bill length: $35.33 \mathrm{~mm} \pm 0.51$; tarsus length: $102.23 \mathrm{~mm} \pm$ 3.27; length of the central toe: $39.98 \mathrm{~mm} \pm 0.87$; body mass: $451.25 \mathrm{~g} \pm 6.29$. Sex could not be determined, as Peruvian Thick-knees lack plumage characters by which sexes may be recognized.

All birds showed an active molt. The primary nearest the bird's body (P1) was the first one to be shed in this tract. The rest of the PP were shed progressively, from the innermost to the outermost and no more than one primary were growing simultaneously. The onset of PP molt generally followed when the tail molt was nearly concluded and most SS were already shed. The molt sequence of SS was much more irregular than the molt progress of PP, although $\leq 2$ SS were being shed at the same time. Individuals with new or growing feathers indicated that they seemed to have two molting centers in this feather tract. Moreover, two birds showed at least two different generations of feathers. The molt pattern of the tail feathers occurred by shedding RR from the outermost pair (R5) to the innermost one (R1). As observed for PP, no more than one rectrix was growing simultaneously.

\section{DISCUSSION}

The night-lighting technique described here was successful for capturing Peruvian Thick-knees in open areas. However, the low trapping chance per capture session influenced negatively the capture success. In most cases, the number of birds captured per session positively correlates with species' abundance (Keyes \& Grue 1982). Thus, the low abundance of Peruvian Thick-knees at the study site (IKA $=1.27-0.47$; Camacho 2010) appears to be the most important barrier to obtain a high capture success. 
On the other hand, the habit of the Peruvian Thick-knee of foraging in close tandem also reduced the number of attempts per session and the success rate, as the capture of the target individuals often caused the other bird to flush. Nonetheless, the success rate of the capturing technique described here ( 0.44 captures/attempt) is comparable to that reported for the selective capture of other open-habitat birds when using the night-lighting technique, such as sandgrouse (0.55 captures/attempt; Benítez-López et al. 2011) or nightjars (0.31 captures/attempt; Jackson 2003). Detection of Peruvian Thick-knees during daylight is often difficult due to their cryptic habits and flocking behaviour (Camacho 2012), but the use of roads during the night by foraging birds may notably enhance the encounter opportunities. Therefore, it is likely that the high densities reported in Peruvian or Chilean populations would maximize the capture success per unit of capture effort where roads are present.

The scarce trapping techniques currently available in the literature for other species in the genus Burhinus require the use of manufactured traps or expensive mist nets, although all materials required for the night-lighting technique are common cheap items obtained at hardware and fishing supply stores. Some methods, as those developed by Andrews (1997), usually work effectively with breeding adults sitting on eggs, but non-breeding birds must be encouraged with food to run them under the trap. In addition, improvements of the night-lighting techniques that involve additional catching equipment (e.g. thermal infrared camera, batteries for strong halogen spotlights, tape player) usually require two persons to guarantee both capture efficiency and bird safety during handling (King et al. 1994, Benítez-López et al. 2011). In contrast, by using a lightweight flashlight and a short plastic pole, a single observer can properly dazzle a bird and simultaneously swing the hand-net downward over it, thus avoiding possible causes of failure (e.g. coordination between the observers, lighting the net when swung downwards or dropping the net too far/close from the bird). Other techniques, as described by Moreno-Opo (2003), do not allow making selective captures. However, whereas conventional capture systems must be developed during daylight, when darkness does not prevent observers from activating or monitoring the traps, the night-lighting technique allows targeting individual Thick-knees when their foraging activity is greatest. In addition, the high fidelity of birds to their foraging sites notably increases the recapture opportunities. This technique also allowed us to capture several Anthony's Nightjars Caprimulgus anthonyi, suggesting that the use of the LED light can be easily adapted for capturing other open-land birds. The high recapture opportunities of this method therefore allows investigating survival rates, natal and breeding dispersal, habitat use, age and sex structure or mating system, as well as many other life-history traits of the Peruvian Thick-knee and possibly other small and medium-sized birds.

Despite the small sample size, this paper first documents the molt patterns and biometrics of free ranging Peruvian Thick-knees. The Peruvian Thick-knee (body length: $380-400 \mathrm{~mm}$, wing length: $228-235$, body mass: $465-460 \mathrm{~g}$ ) is similar in size and proportions to most species in the genus Burhinus (body lengths: $320-480 \mathrm{~mm}$, wing lengths: 200-248 mm, body masses: 290-535 g), except for B. grallarius, considerably larger and heavier than its congenerics (body length: $530-570 \mathrm{~mm}$, wing length: 270-288, body mass: 480-900 g; Marchant \& Higgins 1993, Andrews 1997). The molt sequence of the Peruvian Thick-knee tends to follow the pattern recorded for other temperate species of the genus Burhinus (Marchant \& Higgins 1993, Prater et al. 1977, Giunchi et al. 2008), but some differences exist in the simultaneousness of feather replacement. No overlap between feathers growing from the same tract was recorded in B. superciliaris, except on secondaries. In contrast, B. oedicnemus, a temperate species, usually sheds two or three primaries simultaneously and up to three secondaries during the feather-shedding phase of the molt (Giunchi et al. 2008). This suggests that molting rates in $B$. superciliaris are slower than those in other temperate species, which probably involves an extensive molt-breeding overlap (Moreno 2004). Detailed descriptions of the molt sequence of Peruvian Thick-knees throughout their annual cycle, as well as further research involving marked animals, are needed to fill important gaps in the life histories of this and other species of the same genus.

Acknowledgements. The Ministry of the Environment (Ministerio del Ambiente del Ecuador) issued the permit no. 003-09 IC-FAUDNB/MA for bird monitoring. The comments by two anonymous reviewers helped to improve this work.

\section{LITERATURE CITED}

Aguirre, J., Demanguel, R. \& Canepa, A. 2006. Apuntes sobre la nidificación del Chorlo Cabezón (Burhinus superciliaris) en el norte de Chile. Boletín Chileno de Ornitología, 12: 36-37.

Andrews, L. 1997. The breeding behaviour and success of the Bush Stone-curlew Burhinus grallarius on Magnetic Island. Honours Thesis. Department of Zoology and Tropical Ecology, James Cook University of North Queensland.

Benítez-López, A., Mougeot, F., Martín, C.A., Casas, F., CaleroRiestra, M., García, J.T. \& Viñuela, J. 2011. An improved night-lighting technique for the selective capture of sandgrouse and other steppe birds. European Journal of Wildlife Research, 57: 389-393.

Bishop, R. A. \& Barratt, R. 1969. Capturing waterfowl in Iowa by night-lighting. Journal of Wildlife Management, 33: 959-960. 
Bub, H. 1991. Bird trapping and bird banding: a handbook for trapping methods all over the world. Cornell University Press, Ithaca.

Camacho, C. 2010. Distribución y estado de conservación del Chorlo Cabezón en (Burhinus superciliaris) en Santa Elena, SO Ecuador. Boletín Chileno de Ornitología, 16: 66-73.

Camacho, C. 2012. Variations in flocking behaviour from core to peripheral regions of a bird species' distribution range. Acta ethologica, 15: 153-158.

Canevari, P., Castro G., Sallaberry, M. \& Naranjo, L.G. 2001. Guía de los Chorlos y Playeros de la Región Neotropical. Asociación Calidris. Cali, Colombia.

Cummings, G. E. \& Hewitt, O. H. 1964. Capturing waterfowl and marsh birds at night with light and sound. Journal of Wildlife Management, 28: 120-126.

Drewien, R. C., Reeves, H. M., Springer, P. F. \& Kuck, T. L. 1967. Backpack for capturing waterfowl and upland game by nightlighting. Journal of Wildlife Management, 31: 778-783.

Holmgren, N., \& Hedenstrom, A. 1995. The scheduling of molt in migratory birds. Evolutionary Ecology, 9: 354-368.

Duriez, O., Eraud, C., Barbraud, C. \& Ferrand, Y. 2005. Factors affecting population dynamics of Eurasian woodcocks wintering in France: assessing the efficiency of a hunting-free reserve. Biological Conservation, 122: 89-97.

Hume, R.A. 1996. Family Burhinidae (Thick-knees). pp. 348-363. In: del Hoyo, J., Elliott, A., \& Sargatal, J. (eds.). Handbook of the Birds of the World. Volume 3. Lynx Editions, Barcelona, Spain.

Iannacone, J., Villegas, W., Calderón, M., Huamán, J., Silva-Santiesteban, M. \& Alvariño, L. 2012. Patrones de comportamiento diurno de Huerequeque Burhinus superciliaris en hábitats modificados de la costa central del Perú. Acta Zoológica Mexicana, 28: 507-524.

Keyes, B.E. \& Grue C.E. 1982. Capturing birds with mist nets: a review. North American Bird Bander, 7: 2-1.

Ginn, H.B. \& Melville, D.S. 1983. Moult in birds. BTO Guide 19. Hertfordshire, Reino Unido: British Trust for Ornithology; 112 pp.

Giunchi D., Caccamo C. \& Pollonara E. 2008. Pattern of wing moult and its relationship to breeding in the Eurasian Stone-curlew $\mathrm{Bu}$ rhinus oedicnemus. Ardea, 96: 251-260
Jackson, H. D. 1984. Finding and trapping Nightjars. Bokmakierie, 36: 86-89.

Jackson, H. D. 2003. A field survey to investigate why nightjars frequent roads at night. Ostrich, 74: 97-101.

King D.T., Andrews, K.J., King, J.O., Flynt, R.D., Glahn, J.E. \& Cummings, J.L. 1994. A night-lighting technique for capturing Cormorants. Journal of Field Ornithology, 65: 254-257.

Lindström, J. 1999. Early development and fitness in birds and mammals. Trends in Ecology and Evolution, 14: 343-348.

Marchant, S. \& Higgins, P.J. (Eds) 1993. Handbook of Australian, New Zealand and Antartic Birds Vol 2. pp. 696-708. Oxford University Press, Melbourne.

Miranda, L., Herreros, J. \& Knapton, B. 2001. Observaciones de Burhinus superciliaris en la Región de Tarapacá. Boletín Chileno de Ornitología, 8: 36.

Moreno, J. 2004. Moult-breeding overlap and fecundity limitation in tropical birds: a link with immunity? Ardeola, 51: 471-476.

Moreno-Opo, R. 2003. Cómo capturar alcaravanes. Revista de anillamento, 11: 46.

Prater, A.J., Marchant, J.H. \& Vuorinen, J. 1977. Guide to the Identification and Ageing of Holarctic Waders. pp. 168. BTO Guide No. 17. British Trust for Ornithology. Tring, England.

Ridgely, R. S. \& Greenfield, P. J. 2001. The birds of Ecuador, vol. 1. Cornell Univ. Press, Ithaca, NY.

Santander, T., Hidalgo, J.R. \& Hasse, B. 2006. Aves Acuáticas en Ecuador. Reporte Final. Waterbird Conservation for the Americas. Quito, Ecuador.

Serra L. 2001. Duration of primary moult affects primary quality in Grey Plovers Pluvialis squatarola. Journal of Avian Biology, 32: 377-380.

Summers R.W., Underhill L.G., Nicoll M., Strann K.B. \& Nilsen S.O. 2004. Timing and duration of moult in three populations of Purple Sandpipers Calidris maritime with different moult/migration patterns. Ibis, 146: 394-403.

Svensson, L. 1996. Guía para la identificación de los Paseriformes Europeos. SEO-Birdlife, Madrid.

Ward, D., Nuttalland, R. \& Snyman, A. 1989. An evaluation of some capture techniques for grassland birds. African Journal of Wildlife Research, 19: 77-79. 